\title{
SAVIOURS and SURVIVORS: Darfur, Politics and the War on Terror
}

\author{
Mahmood Mamdani \\ Cape Town: HSRC Press, 2009. Pp.vii +398, ISBN: 978-0-7969-2252-6. Paperback. \\ Reviewed by \\ Lwalzi Siyabonga Lushaba \\ Political Science Department \\ Fort Hare University \\ Alive, 5700 \\ Emal: taungnguru@yahoo.co.ukorllushaba@ufh.ac.za
}

In February 2003, the Durfur Liberation Front (DLF), later to change its name to Sudan Liberation Movement/Army (SLM/SLA), attached and seized the town of Gulu. In response, the Sudanese government launced a brutal counter insurgency. Even though a history of the conflict in Darfur extends a decade and a half earlier to 1987 , it was the violence of the 2003 counterinsurgency which turned Darfur into an object of a concerted global campaign/discourse. Genocide and justice were two coordinates upon which hinged this global discourse. If the Save Darfur Coalition (SDC), western media and American officialdom christened the crisis genocide, the International Criminal Court (ICC) harped on justice - punitive justice, that is.

To validate the genocide claim, western organisations and their intellectual sponsors appealed to colonial historiography. From the intellectual labours of colonial historians had emerged a history of Sudan whose hallmark was the bifurcation of that society into settler Arab and native African (Zurga) races. Locked in a Hegelian dark past, went the logic of this historiography, native Africans signified stagnation to be liberated from it and civilized by settler races, in this case Arabs. 'Arabisation' within which Arab identity acquires an imperical status. Drawn to the present, this narrative impels us to this of the crisis in Darfur as conflict between imperial Arabs and subjugate native Africans.

In July 2008, the ICC indicated President Omar Hasan Ahmad al-Bashir for, amongst other crimes, conspiracy to commit genocide. For those captivated by the racialised narrative of imperialist Arab-Zurga relations handing over President al-Bashir to the ICC set both the inner and outer limits for justice.

In his timely book, Saviours and Survivors, Mahmood Mamdani, subtly but intensely persuades the reader to rethink many of the assumptions that have driven the post-2003 discussions of Darfur. The book is made all the more important by its significance 
beyond the theoretical. At an intellectual level, its major accomplishments are to dispel the myth that the people of Sudan have always been or are best categorised into members of different races, Arab and Zurga, to show that there is not singular history of Arab groups in Sudan, and lastly to marshal sufficient evidence behind the argument that slavery rather than being a foreign Arab institution, was largely a local Fur one (section 2). At level of praxis the book exposes, within the context of Darfur, the folly in the failure to transform the tribal world of natives - a subject of the author's earlier book Citizen and Subject. For weak African states there is in the post-Cold War humanitarian order a real risk of their sovereignty being subverted by the benevolent international community under the pretext of protecting vulnerable populations, the book similarly warns (pp. 271-300).

Setting this work apart from other on Darfur is the dexterity with which the author negotiates his way through grim facts of killing, death and human suffering without letting emotive and moral considerations obscure reason. From an incredible mass of evidence and an expansive array of sources, Mamdani weaves together a timeless treatise presented in accessible jargon without, however, compromising scholarly prescience. Composed of eight chapters, excluding the introduction and conclusion, the book is divided into three sections. The first section interrogates the origins and politics of the Save Darfur Coalition. From inception the SDC shared with official America a singleminded determination to label the conflict in Darfur 'genocide'. However, the number of those dead does not lend credibility to the claim (pp. 25-39). Neither does the United Nations International Commission on Inquiry on Darfur. In its January 2005 report it found that, "the Government of the Sudan has not pursued a policy of genocide... directly or through the militias under its control" (p. 42). Irrespective, the SDC and official America were not deterred. Why and what were the consequences thereof? These questions hold the author's intellectual gaze in the first section of the book.

The second section opens with a survey of two observable strands of Sudanese historywriting. Harold A. MacMichael, an accomplished British colonial administrator, best represents the views of the colonial school. For him, "the history of Sudan before colonialism involved and interaction between native and settler races, with Arab races domination - and civilizing - non-Arab natives" (p.86). Dominated by archaeologist and historically inclined anthropologists the second school, whose lead the author's follows, emerges as a critique of colonial historiography (p. 93). Studying the history of communities from below, the author maintains that there is not "one singular history of Arabs in Sudan but multiple histories" (p. 108). Contrast, for example, riverine Arabs who are settled peoples with Arabs of southern and northern Darfur who are cattle (the Baggara) and camel (the Abbala) nomads respectively. The end-results are multiple local histories; where, in riverine Sudan Arab is an identity of power whilst Darfur Arabs are marginal to power (p. 108).

British colonialists rationalised the shift toward a tribal system of property and 
governance, instituted under rubric of indirect rule, as a return to authentically African social informations. To refute the claim, the book traces the history of the Dar Fur Sultanate from around the mid-1600s with particular emphasis on the Keira dynasty. To consolidate its hold on power, the Keira dynasty took several measures which invariably led to the detribalisation of Dar Fur. These include; dismantling the old tribal land ownership structure and instituting in its place a new land ownership title known in Arabic as hakura given mostly to the new hold man (fuqara); promoting Islam as an alternative ideological system to kinship solidarity thereby welding together a wider transtribal Islamic community (ummah); and recruiting officers into the royal army and other institutions of control from the slave ranks meant to free the king from kin-based authority and power (00.114-136). As a consequence when the Sultanate of Dar Fur collapsed after two-and-half centuries in 1874, Dar Fur was a detribalised community. It is the detribalised pre-colonial Dar Fur that the British would, against the flow of history, seek to retribalise (chapter 5). It is the retribalised society that successive postcolonial regimes reproduced rather than reform.

The last section of the book interrogates two tendencies within the western sponsored discourse on Darfur. First, is the depiction of the war in Darfur as if it was an exclusively north Arab versus south Zurga conflict. Indeed, the conflict was initially between darless camel nomads (Abbala) of the north and the dar-owning sedentary tribes of the south. But, to emphasise only the north-south is to silence the south-south axis of the conflict between dar-owning and darless cattle-nomad (Baggara) tribes of the south. On the balance of evidence this elision was neither coincidental nor driven by ignorance. Acknowledged, it posed the danger of unsettling the racialised Arab-Zurga dichotomy crucial to the genocide claim (pp. 231-243). Second, is the tendency to define justice in retributive terms as though all knowledge gained from theories of transitional justice and the experience of post-conflict societies like Rwanda and South Africa hold no lesson for Sudan (pp.282-288).

Four propositions sum up the book's major arguments: (a) the conflict in Darfur was not a racial one between Arab and Zurga; (b) its causes were numerous including a long environmental crisis which saw the desert encroaching onto northern Darfur thereby pushing Abbala tribes further south; (c) its brutality was a function, not of biology but, militarisation of the region during the Cold War (chapter 7); and (d) the solution to the crisis can neither be a military one nor a single-minded pursuit of justice to the exclusion of reconciliation (conclusion).

One, however, cannot fail to observe, perhaps with consternation, that once the discussion shifts to the post independence period, in the sixth chapter, the people below lose the agency. In a book which scores it's intellectual distinction by pleading the case for the insertion of multiple subaltern histories in the discourse on Darfur that suddenly the national, as opposed to multiple localities, become the loci of politics with every other development deriving its meaning of becoming explicable relative to it, is 
unsettling. Simply the question is, as various post-independence regimes in Khartoum reproduced the tribalised colonial Darfur that had the Keira dynasty been detribalised what were the ebbs and flow in the politics of the governed below?

Noting the effects of the British policy of governing the north and south Sudan as two distict cultural spheres Mamdani writes; "whereas the southern elite saw itself in parochial terms, as no-Arab and southern, the northern elite saw itself as Arab and national (that is, Sudanese)" (p.178). Policies pursued by the northern elite, which has dominated power since independence, including a de facto declaration of Islam as state religion and proclamation of Arabic as the official language, pose a challenge to the author's conception of a Sudanese national identity. What are the norms, boundaries, codes and symbols of this national Sudanese identity - are they ethnic, cultural, religious or civic/political? Or, simply, is being Sudanese tantamount to being an ethnic Arab, as the author implicitly suggests? 